\title{
SULUH
}

JURNAL BIMBINGAN DAN KONSELING

http://journal.umpalangkaraya.ac.id/index.php/suluh

\section{EFEKTIFITAS LAYANAN KONSELING KELOMPOK DENGAN TEIKNIK SELF INSTRUCTION UNTUK MENGURANGI PRASANGKA SOSIAL PESERTA DIDIK DI SIMA NEGRI 2 PALANGKA RAYA}

\section{The Effectiveness Of Groups Conselvation Services Using Self Instruction Techniques To Reduce Students 'Social Preliminary In SMA 2 Palangka Raya}

\section{'Puspita Ayu Prida, ${ }^{2}$ Dina Fariza TS}

Universitas Muhammadiyah Palangkaraya, Jekan Raya, Palangka Raya, Kalimantan Tengah, Indonesia

2 Universitas Muhammadiyah Palangkaraya, Jekan Raya, Palangka Raya, Kalimantan Tengah, Indonesia

\section{ARTIKEL INFO}

Diterima

Juni 2018

Dipublikasi

Agustus 2018

*E-mail:

DinafarizaTS@gmail.com

Orchid:

\section{ABSTRAK}

Penelitian ini bertujuan untuk: (I) Mengetahui tingkat prasangka sosial yang terjadi antar peserta didik sebelum dan sesudah diberikan layanan, (2) Mengetahui layanan konseling kelompok dengan teknik Self instruction dapat mengurangi Prasangka sosial peserta didik. Jenis penelitian yang digunakan adalah Penelitian Eksperimen. Subjek dalam penelitian ini adalah peserta didik kelas X SMA N 2 Palangka Raya tahun pelajaran 2016/2017 yang berjumlah 8 peserta didik. Teknik pengumpulan data yang digunakan adalah skala dan observasi. Analisis data menggunakan uji hipotesis paired sample t-test. Hasil pretest menunjukkan bahwa skors rata-rata skala prasangka sosial peserta didik yaitu 77,50 yang dimana angka tersebut termasuk dalam kategori prasangka sosial yang cukup tinggi sedangkan untuk skors rata-rata posttes peserta didik yaitu 66,75 termasuk dalam kategori sedang. Dari data tersebut menunjukkan bahwa adanya penurunan tingkat prasangka sosial peserta didik setelah dilaksanakan intervensi layanan konseling kelompok dengan teknik selfinstruction.

Kata kunci: Kata Kunci: Prasangka Sosial, Layanan Konseling Kelompok, Teknik self-Instruction

\begin{abstract}
This study aims to: (I) Know the level of social prejudice that occurs between students before and after being given service, (2) Knowing group counseling services with Self instruction techniques can reduce students' social prejudice. The type of research used was Experimental Research. The subjects in this study were class $X$ students of SMA N 2 Palangka Raya in the 2016/2017 academic year, which amounted to 8 students. Data collection techniques used are scale and observation. Data analysis using hypothesis testing paired sample t-test. The pretest results showed that students' social prejudice scale scoring was 77.50, which was included in the category of social prejudice which was quite high while the suspension of posttest scores of students was 66.75 included in the medium category. From these data shows that there is a decrease in the level of social prejudice of students after the group counseling service intervention is carried out with self-instruction techniques.Keywords:
\end{abstract}

Keywords: Social Prejudice, Group Counseling Services, Self-Instruction Technique. 
Jurnal Bimbingan dan Konseling

\section{PENDAHULUAN}

Prasangka sosial sering terjadi di indonesia bahkan telah berkembang dimasyarakat khususnya dikalangan pelajar. Pelajar sebagai generasi penerus perjuangan bangsa, agen perubahan, dan kelompok intelektual muda seharusnya dalam bersikap dan berperilaku mendasarkan diri pada nilainilai intelektual yang selama ini diperoleh, kenyataannya seringkali setiap menghadapi suatu masalah mereka cenderung mendahulukan aspek emosinya. Perkelahian dan tawuran antar pelajar yang sering dimuat di berbagai media massa adalah salah satu contoh bagaimana pelajar menghadapi dan menyelesaikan suatu masalah yang cenderung lebih mengedepankan kekuatan fisik dan emosional.

Dalam hal definisi, prasangka telah mengalami peralihan dan perubahan sepanjang waktu. Dari segi bahasa, kamus besar bahasa Indonesia mengartikan prasangka seebagai suatu pendapat (anggapan) yang kurang baik mengenai sesuatu sebelum mengetahui (menyaksikan, menyelidiki) sendiri. Sementara itu, prasangka yang dalam arti inggris adalah predujice merupakan kata yang berasal dari bahasa latin, yaitu praejudicium yang bererti sebagai sebuah preseden atau penilaian yang berdasarkan pengalaman sebelumnya yang telah terekam (Allport dalam Putra IE \& Pitaloka 20I2: 6)

Prasangka sosial merupakan sikap perasaan orang-orang terhadap golongan manusia tertentu, golongan ras atau kebudayaan yang berbeda dengan golongan orang yang berprasangka itu. Prasangka sosial yang pada awalnya hanya merupakan sikapsikap perasaan negatif itu lambat laun menyatakan dirinya dalam tindakan -tindakan yang diskriminatif terhadap orang-orang yang termasuk golongan-golongan yang diprasangkai itu tanpa terdapat alasan-alasan yang objektif pada pribadi orang yang dikenai tindakan-tindakan diskriminatif. Tindakan- tindakan diskriminatif diartikan sebagai tindakan-tindakan yang bercorak menghambat, merugikan perkembangan, bahkan mengancam kehidupan pribadi orangorang hanya karena mereka kebetulan termasuk golongan yang diprasangkai itu (Gerungan, 2010: 180).

Prasangka sosial di kalangan peserta didik SMA terjadi karena berbagai macam sebab seperti saling pandang, membicarakan teman sekelasnya, dan lain sebagainya. Salah satu contoh kasus akibat prasangka sosial yang dikutip dari detik.com yaitu tawuran antara SMK PGRI Lemah Abang Wadas dengan pelajar SMK Negeri Purwasari. Tawuran tersebut terjadi karena dipicu aksi saling ejek antar peserta didik dari kedua sekolah tersebut. Akibat dari tawuran tersebut satu orang tewas.

Berdasarkan hasil observasi di Sekolah SMA pada hari senin tanggal I5 Agustus 2016, fenomena yang terjadi adalah peserta didik suka membicarakan temannya dan berpikiran negatif terhadap teman sekelasnya, beberapa orang peserta didik berprasangka negatif terhadap jurusan yang lain, tidak menyukai teman sekelasnya serta acuh tak acuh terhadap teman yang tidak disukainya.

Dampak yang ditimbulkan mereka saling tidak bertegur sapa dan tidak menjalin hubungan baik satu sama lain. Peneliti menduga adanya fenomena tersebut terjadi karena tidak adanya penanganan khusus untuk mengurangi prasangka sosial dikalangan peserta didik SMA. Dalam hal ini peran guru BK atau konselor sangat diperlukan untuk membantu mengatasi permasalahan peserta didik dengan menggunakan layanan bimbingan konseling.

Dalam penelitian ini, peneliti menggunakan layanan konseling kelompok untuk mengurangi prasangka sosial peserta didik. Layanan konseling kelompok dinilai dapat mengatasi permasalah peserta didik karena dalam konseling kelompok peserta 
didik mampu mengembangkan diri, mengendalikan diri, dan menemukan potensi yang dimilikinya serta saling mengenal orang lain atau kelompok lain,sehingga mereka dapat berinteraksi satu sama lain dan saling bekerjasama untuk mencapai tujuan.

Konseling kelompok merupakan salah satu diantara beberapa jenis layanan bimbingan dan konseling yang dapat diandalkan, dengan konseling kelompok diharapkan individu dapat berkembang sesuai dengan perkembangannya dan masalah yang dihadapi dapat terentaskan.

Berdasarkan kondisi tersebut, maka konselor akan membantu peserta didik dengan layanan konseling yang dipadukan dengan teknik Self-instruction.

Menurut Friedenberg \& Gilis (Fatimah, 2013: 26I) kegunaan metode self-instruction untuk mengganti pemikiran negatif menjadi positif, didasari oleh pemikiran bahwa pandangan seseorang mengenai dirinya dapat diarahkan. Sementara itu, kegunaan teknik ini untuk mengarahkan perilaku didasari oleh pemikiran bahwa pemberian instruksi merupakan bagian penting pada perkembangan manusia dalam mengarahkan perilaku

Penelitian ini sangat penting dilakukan agar peserta didik dapat saling menjalin hubungan yang baik satu sama lain dan saling bekerjasama untuk mencapai tujuan. Adanya fenomena tersebut, maka peneliti akan melakukan penelitian dengan judul "Efektifitas Layanan Konseling Kelompok dengan Teknik self-instruction untuk Mengurangi Prasangka Sosial Peserta Didik SMA N 2 Palangka Raya”

\section{METODOLOGI PENELITIAN}

Penelitian ini dilaksanakan pada bulan Februari sampai dengan bulan April di SMA N 2 Palangka Raya yang terletak di jalan K.S. Tubun Palangka Raya. Metode yang digunakan dalam penlitian ini adalah metode kuantitatif dengan jenis penelitian eksperimen. Dalam penelitian ini peneliti menggunakan bentuk eksperimen yaitu Pre-Experimental Design. Dikatakan Pre-Experimental Design, karena desain ini belum merupakan eksperimen sungguh-sungguh karena masih terdapat variabel luar yang ikut berpengaruh terhadap terbentuknya variabel dependen. Hal ini terjadi, karena tidak adanya variabel kontrol, dan sempel tidak dipilih secara random.

Populasi penelitian yaitu keseluruhan kelas $X$ di SMA N 2 Palangka Raya. Jenis sampel yang digunakan dalam penelitian ini adalah Sampling Purposive. Menurut Sugiyono (20I5: 85) teknik Sampling Purposive adalah teknik penentu sampel dengan pertimbangan tertentu. Sampel dalam penelitian ini adalah peserta didik kelas $X$ yang memiliki prasangka sosial tinggi yang berjumlah 8 peserta didik.

Teknik pengumpulan data yang dipergunakan adalah sebagai berikut:

a. Observasi

Observasi atau pengamatan adalah alat pengumpulan data yang dilakukan cara mengamati dan mencatat secara sistematik gejala-gejala yang diselidiki. (Narbuko dan Achmadi, 20 I 3: 70)

b. Skala Pengukuran

Skala pengukuran merupakan kesepakatan yang digunakan sebagai acuan untuk menentukan panjang pendeknya interval yang ada dalam alat ukur, sehingga alat ukur tersebut bila digunakan dalam pengukuran akan menghasilkan data kuantitatif. Skala yang digunakan dalam penelitian ini adalah skala Liket. Skala liket digunakan untuk mengukur sikap, pendapat, dan persepsi seseorang atau sekelompok orang tentang fenomena sosial.

Teknik analisis data pada penelitian ini menggunakan rumus Paired Sample T-test yaitu uji hipotesis yang digunakan untuk menguji sampel dengan subjek yang sama namun mengalami dua perlakuan atau pengukuran yang berbeda. 
Jurnal Bimbingan dan Konseling

\section{HASIL DAN PEMBAHASAN}

Berdasarkan hasil penelitian yang dilakukan pada tanggal 04 Maret 2017 di SMA N 2 Palangka Raya terdapat 8 peserta didik kelas $X$ yang teridentifikasi memiliki prasangka sosial tinggi yang didapat berdasarkan hasil pre-test skala prasangka sosial.

Setelah diketahui hasil pre-test, semua peserta didik diberikan intervensi berupa layanan konseling kelompok dengan teknik Self-Instruction untuk mengurangi prasangka sosial peserta didik. Intervensi layanan konseling kelompok dilakukan sebanyak delapan kali pertemuan dengan alokasi waktu sebanyak $2 \times 60$ menit per minggunya

Hasil data menunjukan bahwa Layanan konseling kelompok dengan teknik selfinstruction efektif untuk mengurangi prasangka sosial peserta didik. Hal ini dibuktikan dari hasil rata-rata pretest dan posttest memiliki perbedaan yang cukup signifikan. Berdasarkan hasil hipotesis diketahui nilai sig. (2-tailed) yaitu $0,001<0,05$ yang berarti terdapat perbedaan yang signifikan antara pretest dan posttest.

Hasil pretest menunjukkan bahwa skors rata-rata skala prasangka sosial peserta didik yaitu 77,50 yang dimana angka tersebut termasuk dalam kategori prasangka sosial yang cukup tinggi sedangkan untuk skors ratarata posttes peserta didik yaitu 66,75 termasuk dalam kategori sedang. Dari data tersebut menunjukkan bahwa adanya penurunan tingkat prasangka social peserta didik setelah dilaksanakan intervensi layanan konseling kelompok dengan teknik selfinstruction

\section{KESIMPULAN}

Layanan konseling kelompok dengan teknik self instruction efektif untuk mengurangi prasangka social peserta didik. Hal ini dibuktikan dengan hasil rata-rata pretest dan Posttest peserta didik memiliki perbedaan yang cukup signifikan

\section{DAFTAR PUSTAKA}

Fafaid n. Fatimah, 2013. Penerapan Teknik SelfInstruction Untuk Mengurangi Perilaku Off Task Siswa Kelas X Di Smk Negeri 12 Surabaya. Anterior Jurnal, I, 259-265

Gerungan, 2010. Psikologi Sosial. Bandung: Refika Aditama

Idhamsyah E. Putra \& A. Pitaloka, 2012. Psikologi Prasangka. Bogor: Penerbit Ghalia Indonesia.

Narbuko,C., Achmadi, A,H. 20I3. Metodologi Penelitian. Jakarta: PT Bumi Aksara

$\begin{array}{cll}\text { Sugiyono (2015). } & \text { Metode } & \text { Penelitian } \\ \text { Kombinasi } & \text { (Mix } & \text { Methods). } \\ \text { Bandung: Alfabeta } & \end{array}$

